\title{
Menkes disease
}

INSERM

\section{Source}

INSERM. (1999). Orphanet: an online rare disease and orphan drug data base. Menkes disease. ORPHA:565

Menkes disease (MD) is a usually severe multisystemic disorder of copper metabolism, characterized by progressive neurodegeneration and marked connective tissue anomalies as well as typical sparse abnormal steely hair. 